\title{
Evolutionary benchmarks in sustainability reporting. Incursion from the Brundtland Report to the Sustainable Development Goals
}

\author{
Tatiana DĂNESCU ${ }^{1}$, \\ Radu BOGDAN MATEI ${ }^{2 *}$, \\ Lavinia CONSTANTINESCU ${ }^{2}$
}

\begin{abstract}
${ }^{\prime}$ „, George Emil Palade” University of Medicine, Pharmacy, Science and Technology of Târgu Mureș, 38 Gheorghe Marinescu street, Târgu Mureș, 540139, România

2 „1 Decembrie 1918” University”, Alba -Iulia, 5 Gabriel Bethlen street, 510009, România
\end{abstract}

\begin{abstract}
Sustainable development has become, at a rapid pace, outright desirable, an essential condition for all companies, and the business strategy must be based on transparency and accountability, and the information published must be the architecture of sustainable reporting. This is because the public reports of the companies generate the essential platform that reflects the performance, the social and environmental impact, as well as a subsidiary marketing function through which new customers and investors are attracted, as well as talented employees. The main objective of this research is to identify the main landmarks of the evolution of sustainability reporting in the dimension of non-financial reporting standards applied by Romanian companies. The migration trend from conventional to sustainable accounting is evident, with the latter including a variety of social and environmental issues such as: biodiversity protection, climate change, energy efficiency, greenhouse gas emissions, waste management, social inclusion disadvantaged people, respect for human rights, the fight against corruption and transparency of information.
\end{abstract}

Keywords: sustainability, Brundtland Report, UN Agenda 21, Sustainable Development Goals.

Clasificare JEL: $M 41, M 42, Q 01$

(C) 2021 Published by ACTA MARISIENSIS, SERIA OECONOMICA, Publisher University Press Targu Mures, issued on behalf of University of Medicine, Pharmacy, Sciences and Technology "George Emil Palade" from Targu Mures, Romania.

${ }^{*}$ Corresponding author: Matei Radu Bogdan

e-mail: radubogdanmatei@gmail.com 


\section{INTRODUCTION}

The difficult times in the world, caused by the economic and social difficulties, including the effects of the current pandemic crisis, have put new challenges on the agenda of companies for the resilience of companies that do not lack clear actions that produce changes in the financial reporting process.

The role of companies in society has been reconsidered, they are instructed to give up the defensive attitude adopted in relation to civic associations and to take a proactive approach, to have a sustainable business strategy, well defined, with activities that have a positive and longterm impact. in the future of ecosystems, community and can be credibly reported.

Sustainability reporting enjoys an overflowing enthusiasm at the moment, being considered a free advertising program for the company, a way to attract new customers, improve the image and reputation in the market. This type of reporting is much more complex and involves synergy between different departments such as legal, financial-accounting, environment, human resources, marketing. It also involves changing organizational thinking, so that managerial decisions aim at creating long-term value, promoting corporate responsibility and broad stakeholder involvement.

Natural resources have been considered unlimited in the past, which is why in the next period, areas of the Earth will appear without water, energy or gas resources. The expected dangers from this point of view have led to the setting of concrete actions on the agenda of international bodies for the identification and monitoring of major United Nations (UN) conferences and meetings, which set the deadline for sustainable development. The Millennium Development Goals and the Sustainable Development Goals were also detailed, and were taken over by the European Union, which aims to become a leader in the implementation of these goals.

\section{DEFINITION OF THE RESEARCH PROBLEM}

\subsection{Sustainable reporting-the new accounting paradigm}

At European level, the non-financial information that is required to be published by any company of public interest, which at the balance sheet date exceeds the average number of 500 employees, is regulated by Directive 2014/95/EU. In Romania, this Directive was transposed by Order of the Minister of Public Finance no. 1938/2016, so companies can choose to present nonfinancial information in the form of a non-financial statement or through an integrated, independent report, which through the objectives to be addressed is called a sustainability report. Regarding the mandatory information imposed by these two normative acts, the most important ones we want to emphasize are: the presentation of information relevant to environmental issues, personnel, social policies, respect for human rights, the fight against corruption and bribes. It also imposes rigor on the business model and policies adopted by the company, the relevant risks and key performance indicators.

The emergence of Directive 2014/95/EU brings at least three significant and novel elements (Garcia et al, 2022):

- contributes to the transparency of information provided by companies by highlighting their impact in areas such as society, the environment and human rights; 
- the introduction of the requirement to publish non-financial and diversity information improves the communication relationship between the company and stakeholders;

- contributes to long-term economic growth, through measures that can be taken following the analysis to streamline the company's impact on the environment and the local community.

The first sustainability reports were published in the late ' 80 s by: companies in the chemical industry because they had serious image problems, small and medium-sized companies with very advanced environmental management, tobacco companies that had the strategic goal of attracting new investors during the period when business ethics grew significantly in popularity.

This trend of sustainability reporting has developed progressively over the last 30 years, with the main goal of increasing the transparency of information and asserting responsibility in business. According to a study conducted on companies indexed in the S\&P 500 (KPMG- Business Reporting, 2016), in 2011 only $20 \%$ of companies reported information on the ecological and social component, so that in $2016,90 \%$ of them complied reporting requirement. Thus, it is found that, globally, the reporting and disclosure of ESG (Environment, Social, Governance) aspects has experienced a significant increase, companies being aware of the need to implement transparency and long-term value creation.

Conceptually, research has recently focused on sustainable accounting, extrapolating conventional accounting to a variety of environmental and ethical issues, including: energy efficiency, biodiversity, greenhouse gas emissions, waste management, employee health and safety (Horisch et al, 2020). To conduct research on the concept of sustainable development, it is necessary to know and analyze the causes of environmental damage, because the development of a company through uncontrolled deforestation, water pollution by discharging into nearby rivers or intensive fishing, lead to the collapse of natural ecosystems.

In terms of etymology, the term sustainable development comes from the English language (sustainability, sustainable development) and represents the ability to exist constantly or the ability of the biosphere and human civilization to coexist.

We consider it appropriate to take a holistic approach to sustainable development, with a long-term view of the link between quality of life and the environment having the expected effect when the results of these actions will be palpable, clear and concrete. For humanity, a moderate level of resource consumption, a healthy natural environment, strong public institutions and favorable to social and digital inclusion would be ideal (Durning, 1992).

Sustainable reporting is considered a key platform for communicating performance and its impact on the community and the environment. There are many benefits that a company that has adopted this type of reporting has, of which (Almășan et al, 2019):

- "Increasing the reputation on the market (image, marketing technique);

- Satisfying the expectations of stakeholders;

- Easy access to the capital;

- Increasing efficiency and productivity;

- Waste reduction through their efficient management;

- Fast, accurate assessment and comparability."

Cost efficiency is a priority for any company that wants a sustainable, healthy business that can get through difficult times without sacrifice. Reporting on the social and environmental aspects 
of a company involves direct and indirect costs such as: direct implementation costs, with staff training projects, payment of fees of external verifies, costs of efficient distribution and reporting of information. Companies with poor social and environmental performance may also have a number of additional indirect costs that are caused by declining profits, losses of talented employees, investors or customers in contrast to performing and non-financially performing companies (Ienciu et al, 2014).

The development of the modern society at a fast pace, automatically requires the continuous improvement of the information that a company has to offer to the interested parties. Thus, information is considered an essential element for progress and for making managerial decisions. Producers of financial and non-financial information play an important role, as they represent a "database" made available to management that reflects the company's micro and macroeconomic performance (Agănencei et al, 2021).

The company's activities to create added value are considered sustainable by capital market stakeholders. Managers integrate such actions into their business strategy, but they do not translate directly into increasing a company's profit, because we have to take into account the high implementation costs (Ryu, H. \& Chae, S., 2022).

Sustainability reporting has long been considered a voluntary action, but after the publication of the European Directive on the publication of non-financial and diversity information, it was necessary to present certain issues considered relevant. The development of this type of reporting can be associated with the evolutionary process of society, drawing attention to the need for more transparent information (Tiron et al, 2019). We conclude that this process is gradually leading to an awareness of the importance of such reports among managers.

\subsection{Research methodology}

The main objective of this research is to identify the main landmarks of the evolution of sustainability reporting in the dimension of non-financial reporting standards applied by Romanian companies.

The method used in conducting this research is the analysis of the literature considered representative at national and international level in the context of the research conducted. The review of the literature in the field of sustainability reporting was done by documenting the articles published in the Web of Science and Google Scholar databases, but also on some well-known volumes in this field. Subsequently, a critical comparative analysis was performed, followed by the synthesis and contextualization of the issue to obtain a representative picture of the evolutionary benchmarks regarding the objectives of the UN Agendas, but also on the reports established by applying the published Global Reporting Initiatives Standards.

In order to establish the key information related to the research topic, the numerous standards in terms of sustainable development, environmental standards, safety and security at work were also taken into account, the choice being difficult due to the lack of comparability of some information contained. The difficulty in carrying out the comparability procedure is due to the fact that the topic of sustainability has been the subject of work of authorities and professional bodies in different fields of activity (social, environmental, economic), with specific visions, but anchored in the sustainable development strategy, a jurisdiction. 


\section{RESEARCH RESULTS}

\subsection{Brundtland Report-1987}

In 1987, the United Nations (UN) World Commission on Environment and Development published the report Our common future, later called the Brundtland Report after the former Norwegian Prime Minister Harlem Brundtland. The Brundtland report is seen as a global agenda for change, for a more prosperous, just and secure future, emphasizing the need for urgent action. This report has undoubtedly been a real catalyst for the world's unprecedented concern for the environment.

For the first time, the term sustainability appears, becoming the most well-known, classic and quoted definition in the field. Sustainability is defined (Brundtland, 1987) as "meeting present needs without sacrificing the ability of future generations to meet their own needs." This statement has become a global phenomenon, being naturally incorporated into the economic world, sustainability becoming a popular value of acceptable development (Borowy, 2014).

Following the publication of the Brundtland Report in 1987 and the enactment of the first objectives, key issues in addressing sustainability were highlighted. Among the most important areas where concrete actions are needed are fundamental human rights, the implementation and monitoring of environmental management standards and systems, equal and non-discriminatory access and treatment or the peaceful settlement of disputes through a global partnership.

The Brundtland report firmly states that sustainable development is a key component of the development of international thinking, which, if implemented, will bring many long-term benefits to the states involved. It also helps to activate consolidated goals, namely improving human well-being, equitable distribution of resource use within and within companies, a development that ensures the ecological integrity of future generations (Sneddon, Howart \& Norgaard, 2006).

\subsection{UN Agenda $21-1992$}

The Conference on Environment and Development was held in Rio de Janeiro, Brazil, on 3-14 June 1992, and the UN adopted Agenda 21. During this period, the term sustainable development is becoming more widely known. being the establishment of a global strategy on sustainability and the three related pillars. The final document contains 351 pages, being divided into 40 chapters and 4 main sections. It was adopted by the 178 governments present at the conference in 1992, the result of 4-5 years of hard work, numerous public consultations and negotiations. The conclusion presented calls for greater attention to be paid to the environment and sustainable development, to the involvement of clear and concrete actions on the part of all participants, the future benefits of which will be a substantial improvement in the standard of living.

Emphasizes that, through proper environmental management and the protection of the community, a more prosperous future will be possible for all mankind; "No nation will succeed alone, but together we can, through a global partnership for sustainable development" (UN Agenda 21, 1992). Constructive dialogue has been a key element in building global partnership and has been inspired by the need for a more efficient and equitable world. The adoption of Agenda 21 by 
all nations present at the conference has created an unprecedented partnership to reverse the effects of the degradation of the environment of this planet (Sitarz, 1993).

Sustainable development, unfortunately, is not being achieved in a uniform manner in all countries. In terms of EU countries (Tarquinio et al, 2018), Spain, Italy and the United Kingdom are considered to be the most developed and with a quality of sustainability reports considerably higher than the rest of the countries. The proof is provided by the companies from the countries mentioned above, which have demonstrated through published reports communication and professionalism over time.

\subsection{Millennium Development Goals (MDGs) - 2000}

In 2000, the Millennium Summit - The Role of the UN in the 21st Century, was held in New York, considered the largest gathering of world leaders in its history with the participation of 189 countries, including Romania.

This agenda is considered global, and with the assumption of it by the heads of state and their governments, a high-level agreement has been reached, creating the levers to monitor human development, national resources and strengthening partnerships between the signatory states.

During this international conference, the Millennium Development Goals were formulated, the main goal being to replace previous UN initiatives, being very carefully demarcated over time. Given that they were formulated in a period of prosperity, called by specialists as the most prosperous period of the economy, the pact was also signed by the poor, developing and landlocked poor countries, in a period of conflict and fasting. -conflict. These objectives have been considered by some economic actors as "minimum objectives", as evidenced by the fact that some states have achieved them within 10 years because governments have the necessary resources, knowledge and technology.

\subsection{UN 2030 Agenda - Sustainable Development Goals (SDGs)}

On September 25-27, 2015, the UN Conference takes place in New York, which adopted the 2030 Agenda called Transforming Our World. The Conference adopted the 17 Sustainable Development Goals (SDGs), 169 targets to be achieved and 241 progress monitoring indicators, being developed by the Inter-institutional Group of Experts on the SDGs and approved by the Statistical Commission in March 2016. These goals demonstrate the breadth of the Agenda, which, based on the Millennium Development Goals, has as its main objective the resolution of unresolved issues.

The objectives of the 2030 Agenda are integrated and indivisible, and the actions will be undertaken and monitored over 15 years. Significant differences in development were found among the signatory countries, but through the Agenda the signatories undertook not to leave anyone behind in this common journey (Agenda 2030, 2015).

Agenda 2030 offers a universal target system, covering a wide range of topics, including key areas such as 5P: people, planet, prosperity, peace, partnership (Eichhorn, Hans, \& Schon, 2021). 
Table no. 1 The main evolutionary landmarks of sustainability reporting

\begin{tabular}{|c|c|c|c|c|c|c|}
\hline & Date & Location & $\begin{array}{c}\text { Partici } \\
\text { pants }\end{array}$ & $\begin{array}{c}\text { Implement } \\
\text { ation } \\
\text { period }\end{array}$ & Purpose & Objectives \\
\hline Agenda 21 & $\begin{array}{l}\text { June } \\
1992\end{array}$ & $\begin{array}{l}\text { Brazilia - } \\
\text { Earth } \\
\text { Summit }\end{array}$ & 178 & $1992-2000$ & $\begin{array}{l}\text { Each local } \\
\text { government } \\
\text { should } \\
\text { develop a } \\
\text { local agenda } \\
\text { for sustainable } \\
\text { development }\end{array}$ & $\begin{array}{l}\text { 4 Sections: } \\
\text { 1) The social and economic dimension } \\
\text { (combating poverty, promoting health, } \\
\text { changing the type of consumption) } \\
\text { 2) Conservation and Management of } \\
\text { Development Resources (combating } \\
\text { deforestation, biodiversity conservation, } \\
\text { pollution control) } \\
\text { 3) Strengthening the role of major } \\
\text { groups (the role of children and women, } \\
\text { the role of local authorities and } \\
\text { community) } \\
\text { 4) Means of implementation (science, } \\
\text { technology, financial mechanisms) }\end{array}$ \\
\hline ODM & $\begin{array}{l}\text { Sept. } \\
2000\end{array}$ & $\begin{array}{l}\text { New York - } \\
\text { Millennium } \\
\text { Summit }\end{array}$ & 191 & $2000-2015$ & $\begin{array}{l}\text { Global } \\
\text { partnership to } \\
\text { reduce } \\
\text { extreme } \\
\text { poverty }\end{array}$ & $\begin{array}{l}\text { 1) Elimination of severe poverty and } \\
\text { hunger. } \\
\text { 2) Universal access to primary } \\
\text { education. } \\
\text { 3) Promoting gender equality and } \\
\text { encouraging women. } \\
\text { 4) Reducing infant mortality. } \\
\text { 5) Improving maternal health. } \\
\text { 6) Fighting HIV / AIDS, malaria and } \\
\text { tuberculosis. } \\
\text { 7) Ensuring environmental } \\
\text { sustainability. } \\
\text { 8) Creating a global partnership for } \\
\text { development. }\end{array}$ \\
\hline Agenda 2030 & $\begin{array}{l}\text { Sept. } \\
2015\end{array}$ & $\begin{array}{c}\text { New York - } \\
\text { Transf. lumii } \\
\text { noastre }\end{array}$ & 193 & $2015-2030$ & $\begin{array}{l}\text { Strengthening } \\
\text { universal } \\
\text { peace and } \\
\text { ensuring } \\
\text { freedom }\end{array}$ & $\begin{array}{l}\text { 17 SDG / } 169 \text { Targets to be achieved } \\
\text { They include the } 8 \text { MDGs plus } 9 \text { new } \\
\text { targets } \\
\text { 1) Access to water distribution and } \\
\text { sanitation services } \\
\text { 2) Reliable, sustainable and affordable } \\
\text { energy services } \\
\text { 3) Sustained, inclusive growth } \\
\text { 4) Development of resilient } \\
\text { infrastructure } \\
\text { 5) Reducing inequalities between } \\
\text { countries } \\
\text { 6) Development of resilient cities } \\
\text { 7) Combating climate change } \\
\text { 8) Conservation of seas and oceans } \\
\text { 9) Protecting and restoring terrestrial } \\
\text { ecosystems }\end{array}$ \\
\hline
\end{tabular}

Source: authors' processing according to UN Agenda 21, MDGs and Agenda 2030. 


\subsection{Legislative elements regulating sustainability reporting}

The existence of a wide range of general frameworks, rules and regulations on nonfinancial reporting makes the reporting process difficult as companies face the dilemma of choice. The International Federation of Accountants (IFAC) considers it essential that regulators, standard-setters and other stakeholders focus to reach a consensus on identifying consistent and globally consistent practices and commitments (IFAC, 2017).

\section{a) Directive 2014/95 / EU on the presentation of non-financial information}

Since 2014, the "Single Market Act - 12 levers to boost growth and strengthen confidence" has introduced the size criterion in the reporting, so that public interest entities that at the balance sheet date exceed the average number of 500 employees are required to include in the published report, a non-financial statement containing the information considered mandatory under Directive 2014/95 / EU:

- Information on social, personnel, environmental policies, respect for fundamental human rights, combating bribery and corruption;

- Brief description of the company's business model;

- Description of the policies adopted and the due diligence procedures;

- The results of the policies described above;

- The main risks arising from the company's activity, the products / services that may have a negative impact;

- Key indicators of non-financial performance for the activity carried out.

The companies, through their own management, have the alternative to publish the nonfinancial statement in the Directors' Report or to draw up an integrated report, independent of the financial reporting. If a separate report is prepared, independently of the classical financial reporting, it shall include the required non-financial information and shall be made public by making it available to the general public within a reasonable time. This period must not exceed six months from the date of publication of the financial statements, be available on the company's website and there must be a statement in the management report on non-financial matters.

b) Order of the Minister of Public Finance (O.M.F.P) no. 1938/2016 on amending and supplementing certain accounting regulations.

This normative act represents the transposition in the national legislation of the Directive 2014/95/EU, regarding the non-financial information. In order to respond to non-financial disclosure requests, companies can rely on national, European or international frameworks or create their own reporting standards. The provisions of this act are not limiting and the decision of non-financial reporting is at the discretion of the company. 
Table no.2 Relevant social and environmental aspects in O.M.F.P no. 1938/2016

\begin{tabular}{|c|c|}
\hline Issues related to social inclusion & Environmental issues \\
\hline Actions taken for gender equality & $\begin{array}{l}\text { Current and foreseeable future impact on } \\
\text { the natural environment and ecosystems }\end{array}$ \\
\hline Working conditions & Increasing the share of renewable energy \\
\hline Respect for trade union rights & Greenhouse gas emissions \\
\hline Occupational health and safety & Rational use of water \\
\hline Prevention of human rights abuses & $\begin{array}{c}\text { The negative consequences of climate } \\
\text { change }\end{array}$ \\
\hline Tools to fight corruption and bribery & The air pollution \\
\hline
\end{tabular}

\section{c) United Nations Global Compact (UNGC)}

Regarding the mission of this organization, its main concern is to create a global movement of companies for sustainability. So, in addition to companies that have joined and use sustainability practices, referrals are made to stakeholders to contribute to the world we all want. The organization supports companies to develop socially responsible businesses, with operations and strategies aligned with the 10 UNGC principles.

Table no.3 Principles of the United Nations Global Compact

\begin{tabular}{|c|c|c|}
\hline Field & Principle & Purpose \\
\hline \multirow[t]{2}{*}{ Human rights } & No. 1 & $\begin{array}{l}\text { Companies must support and respect internationally } \\
\text { proclaimed human rights }\end{array}$ \\
\hline & No. 2 & $\begin{array}{c}\text { Companies must not be complicit in human rights } \\
\text { violations }\end{array}$ \\
\hline \multirow[t]{4}{*}{ Labour } & No. 3 & $\begin{array}{l}\text { Companies must uphold freedom of association and } \\
\text { the recognition of the right to collective bargaining }\end{array}$ \\
\hline & No. 4 & $\begin{array}{l}\text { Companies must eliminate all forms of forced and } \\
\text { compulsory labor }\end{array}$ \\
\hline & No. 5 & Companies need to eliminate child labor \\
\hline & No. 6 & $\begin{array}{c}\text { Companies need to support the elimination of } \\
\text { discrimination in employment }\end{array}$ \\
\hline \multirow[t]{3}{*}{ Environment } & No. 7 & $\begin{array}{c}\text { Companies need to support the cautious approach to } \\
\text { environmental challenges }\end{array}$ \\
\hline & No. 8 & $\begin{array}{c}\text { Companies need to take initiatives to promote } \\
\text { environmental responsibility }\end{array}$ \\
\hline & No. 9 & $\begin{array}{l}\text { Companies need to encourage the development of } \\
\text { green technologies }\end{array}$ \\
\hline Anticorruption & No.10 & $\begin{array}{l}\text { Companies need to work against corruption in all its } \\
\text { forms, including bribery }\end{array}$ \\
\hline
\end{tabular}




\section{d) Global Reporting Initiative (GRI) Standards}

GRI standards are the best known and most used globally, being used mainly by Romanian entities. The role of GRI Standards is to support companies in preparing the sustainability report. Any company that reports in accordance with GRI standards must adhere to the recommended reporting principles. GRI standards propose a set of 10 reporting principles (GRI, 2020), necessary for a conclusive report:

- 4 principles regarding the content of the non-financial report: materiality, stakeholder involvement, sustainable development and completeness;

- 6 principles regarding the quality of the non-financial report: accuracy, comparability, reliability, timeliness, clarity, fairness.

\section{Figure no. 1 Structure of the Global Reporting Initiative (GRI) Standards}

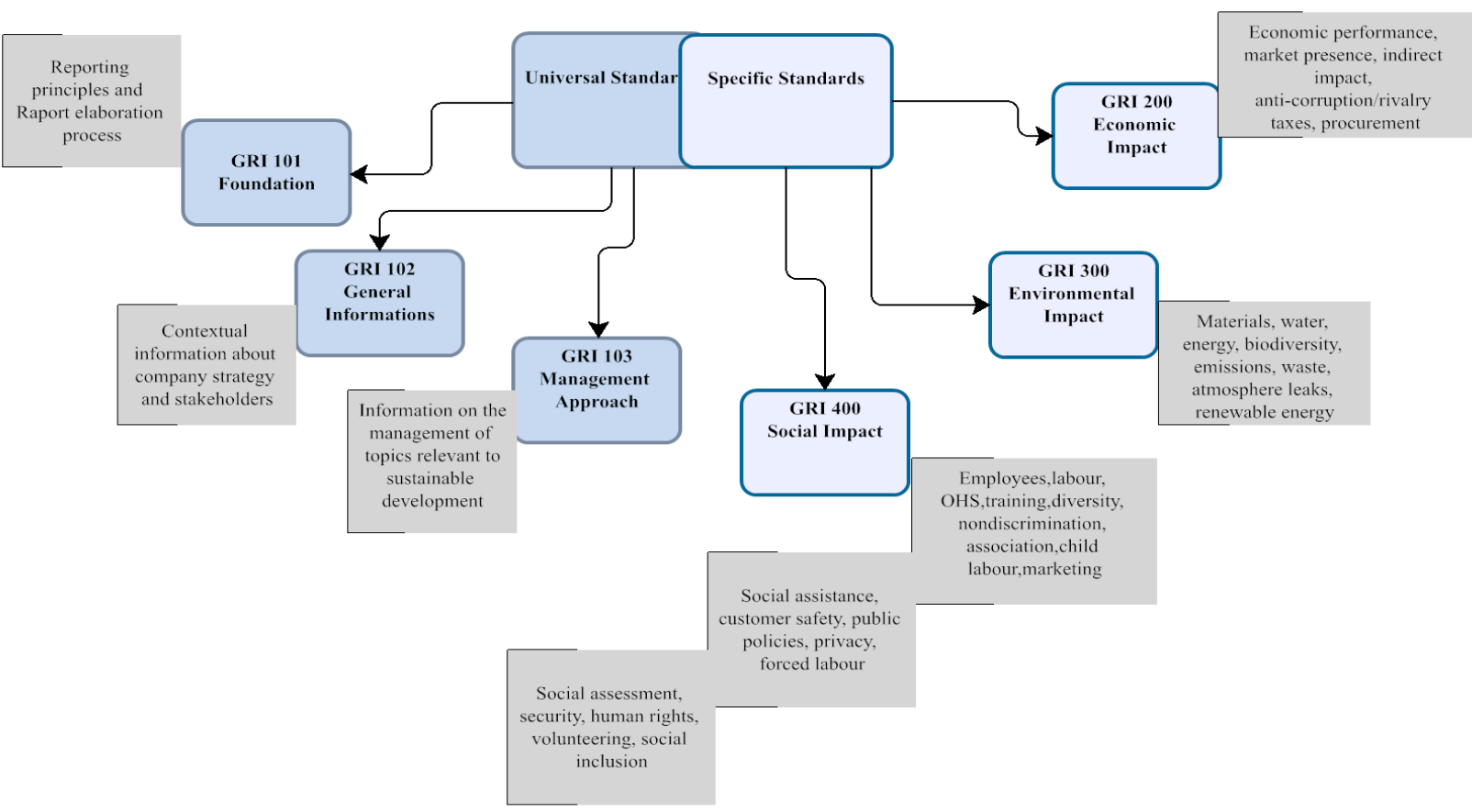

Source: authors' processing according to GRI Standards.

In order to facilitate the understanding of information by stakeholders, the efficient preparation of the non-financial report, but also to differentiate between mandatory and voluntary reporting, companies have the opportunity to fully comply with GRI standards or to integrate only specific sections. In the following table, a brief overview of the 3 types of reports (Core, Comprehensive, Referenced) can be seen. 
Table no. 4 Types of reports provided by GRI Standards

\begin{tabular}{|l|l|l|l|}
\hline Types of reports & \multicolumn{1}{|c|}{ Core Report } & \multicolumn{1}{c|}{ Comprehensive Report } & \multicolumn{1}{c|}{ GRI Referenced Report } \\
\cline { 2 - 4 } & $\begin{array}{l}\text { Contains the minimum set of } \\
\text { information needed to understand } \\
\text { the company's impact on } \\
\text { sustainable development and } \\
\text { how it is managed }\end{array}$ & $\begin{array}{l}\text { Contains the information presented } \\
\text { above, is done on a much more } \\
\text { advanced scale, requiring information } \\
\text { on strategy, ethics, integrity and } \\
\text { corporate governance }\end{array}$ & $\begin{array}{l}\text { Solution for companies that want to } \\
\text { report certain relevant issues on social, } \\
\text { economic and environmental impact, } \\
\text { but do not use the standards for the } \\
\text { report overview }\end{array}$ \\
\hline
\end{tabular}

Source: authors' processing according to GRI Standards.

The literature also includes a variety of other non-financial reporting frameworks used by national and international companies, but as more and more stakeholders say, there are difficulties in comparing them. These reporting frameworks include: Forest Stewardship Council, Social Accountability 8000, ISO 14001: 2015, ISO 26000: 2010, ISO 45001, ISO 18001 and AccountAbility Principles AA1000.

\section{CONCLUSIONS}

Promoting sustainable development in the business landscape of any kind is essential, as managers need to understand that short-term profit is not a concern for investors, as the occurrence of natural or biological disasters, the frequency of social disturbances or the disappearance of essential resources can affect business prosperity. medium and long term. Companies that take sustainable development actions respond positively to current challenges and act accordingly, thus gaining a competitive advantage. The Global Compact is the unequivocal supporter of the 2030 Agenda, which set the 17 Sustainable Development Goals, and is actively promoted by working to mobilize companies to fight poverty, combat climate change and ensure that no one is left behind.

The need to implement non-financial reporting at the international level is in line with the consequences of economic, social, political, medical or natural events that society has gone through in recent decades. Profit and strictly financial indicators are no longer considered sufficient to demonstrate the performance of a company. We consider that the essential moment of the development of this type of reporting was the appearance of the Directive 2014/95 / EU, transposed in the national legislation by OMFP no.1938 / 2016. Starting with 2017, there is an obligation to report non-financial issues by all companies of public interest which, at the date of submission of the balance sheet, exceed the average number of 500 employees. Increasing the reputation of the market, the positive image of the company, meeting material issues for stakeholders, easy access to the capital market or reducing indirect costs are important benefits for a company that carries out corporate social responsibility actions and adopts a development strategy durable. There are currently a variety of non-financial reporting frameworks used internationally. Of the studies analyzed and research conducted, the most widely used are the Global Reporting Initiatives Standards, considered by entities to be the best documented. They are a starting point in drawing up a sustainability report, offering comparability between companies and, implicitly, by sectors of activity. In addition to these standards, regulators have developed other sustainable reporting frameworks.

It is clear that non-financial reporting has become much more than an end in itself today. Non-financial reporting transcends its classic role of informing stakeholders and becomes an active 
marketing tool that companies that have understood its operating mechanism operate in accordance with their strategic objectives, turning it into an extremely valuable competitive advantage. which brings to the forefront the responsibility - perceived as the foundation of the economic, ethical and ecological progress of the business.

\section{Bibliography:}

Agănencei, M., Gherman, E., Venter, G., Feher, A., Sîrbulescu, E., (2021). The role of financial accounting information in the sustainable development of the company, Lucrări Științifice Management Agricol, Vol. 23, Issue 1, pg. 337-342.

Agenda 2030. (2015). Transformarea lumii noastre. New York.

Agenda 21. (1992). Sustainable development.Rio de Janeiro: Organizația Națiunilor Unite.

Almășan, A., Circa, C., Dumitru, R., Guse, R., \& Mangiuc, D. (2019). Effects of Integrated Reporting on Corporate Disclosure Practices Regarding the Capitals and Performance. Amfiteatrul Economic, 21(52), 572-589.

Borowy, I. (2014). Defining sustainable development for our common future. A history of the WCED. London: Earthscan from Routledge.

Brundtland, C. (1987). Our common future.Oxford University Press.

Directiva 2014/95/UE. (2014). Directiva privind prezentarea informațiilor nefinanciare și diversitate.

Durning, A. (1992). How Much is Enough? The Customer Society and the Future of Earth. Londra: Norton Worldwatch Environmental.

Eichhorn, S., Hans, M., \& Schon, M. (2021). A participatory Multi-Stakeholder Approach to Implementing the Agenda 2030 for Sustainable Development. Theoretical Basis and Empirical Findings. Springer.

Garcia, M., Bollas, A., Sierra, G. (2022). Non-financial reporting in Spain. The effects of the adoption of the 2014 EU Directive, Spanish Accounting Review, Vol. 25, Issue 1, pg. 3-15

GRI. (2020). Accesat pe data de 02.10.2021,Global Reporting Initiative Standards: http://www.globalreporting.org/how-to-use-the-gri-standards/gri-standards-english-language/

Horisch, J., Schaltegger, S., \& Freeman, R. (2020). Integrating stakeholder theory and sustainability accounting: A conceptual synthesis. Journal of Cleaner Production, 275.

Ienciu, I., Muller, V., Popa, I., Bonaci, C., Studiu privind raportarea non-financiară conform reglementărilor europene în cadrul societăților românești, Revista Audit Financiar, Vol. 117, Issue 9, pg.46-50

IFAC. (2017). Imbunătățirea raportării organizaționale: Cheia raportării integrate.

KPMG - Raportarea în afaceri (2016).

ODM. (2010). Accesat pe data de 02.08.2021, Obiectivele de dezvoltare ale mileniului: https://eurlex.europa.eu/summary/RO/dv0014

OMFP nr.1938. (2016). Ordinul Ministrului Finanțelor Publice nr.1938/2016 privind modificarea şi completarea unor reglementări contabile.

Ryu, H., Chae, S., (2022). The work experience of internal control personnel and corporate social responsability, Academy of Accounting and Financial Studies Journal, Vol. 26, Issue 1, pg. 1-9.

Pactul Global al Națiunilor Unite. Accesat pe data de 01.11.2021, https://www.unglobalcompact.org/whatis-gc/mission/principles

Sitarz, D. (1993). Accesat pe data de 01.11.2021, Agenda 21: The Earth Summit to save our planet: www.web.osti.gov/biblio/6289330

Sneddon, C., Howart, R., \& Norgaard, R. (2006). Sustainable development in a post-Brundtland world. Ecological Economics, 57, 253-268.

Tarquinoi, L., Raucci, D., Benedetti, R., (2018), An Investigation of Global Reporting Initiative Performance Indicators în Corporate Sustainability Reports: Greek, Italian and Spanish Evidence, Sustainability, Vol. 10, Issue 4, pg 1-19.

Tiron, A., Nistor, C., Ștefănescu, C., Zanellato, G. (2019). Encompassing Non-Financial Reporting in A Coercive Framework for Enhancing Social Responsibility: Romanian Listed Companies' Case. Amfiteatrul Economic, Vol. 21, Issue 52, pg. 590-606 